\title{
Employee Benefits Accounting, Its Impact on the Market Share Price, the Volume of Credit Facilities and Deposits
}

\author{
Mohammad Hamdan $^{1}$, Marie Bany Khaled ${ }^{1} \&$ Sakhr Bany Khaled ${ }^{1}$ \\ ${ }^{1}$ Faculty of Economics and Administrative Sciences, Al al-Bayt University, Jordan \\ Correspondence: Mohammad Hamdan, Department of Accounting, Al Al-Bayt University, Jordan. E-mail: \\ mohd_naser78@yahoo.com
}

Received: November 3, 2017

Accepted: November 16, 2017 Online Published: December 5, 2017

doi:10.5539/ijef.v10n1p23

URL: https://doi.org/10.5539/ijef.v10n1p23

\begin{abstract}
This study aims to examine the impact of employee benefitsaccounting (direct and indirect compensation) on (market price, volume of credit facilities and volume of deposits). The study community is represented by commercialbanks listed on the Amman Stock Exchange (ASE), all the continuous banks whose financial data were available during the study period (2007-2015) were selected represented in (13) banks. In order to realize the objectives of the study, the study was based on qualitative data and analytical descriptive method (Panel Data), (E-Views) economic statistics software was used to test hypotheses. The results of the study showed that there is a statisticallysignificant impact on both typesof employees compensations as a whole (direct and indirect) on the market share price, the volume of credit facilities and the volume of deposits. While the results of the study confirmed that the indirect compensation has not got an impact on the volume of customer deposits when it is measured separately. Finally, the study recommended the need to apply good systems that take into account the interest of both the employers and employees for the positive impact on the market share price, the volume of credit facilities and the volume of deposits.
\end{abstract}

Keywords: employee benefit accounting, market share price, volume of credit facilities, volume deposits

\section{Introduction}

The modern standards of employee benefit accounting do not care about a specific group of the society and neglects others, but rather it extended to a national level that cares about all members of society, whether those working in the government, private or cooperative sector, the army or self-employed as craftsmen and freelancers and businessmen or practicing industrial activity, etc. (Locke, Rissing, \& Pal, 2013), whether employment office located within the State or abroad (Glaum, Keller, \& Street, 2017). In June 2011, the Financial Accounting Standards Board (FASB) revised International Accounting Standard- Employee Benefits (IAS, 19) in respect employee benefit accounting, including removing the option that allows business organizations to defer recognition of changes in the identified net benefit obligation, and adjusted certain disclosure requirements of employee benefit accounting (Arab Society of Certified Accountants (ASCA), 2015) (Note 1). In addition, it requires that business organizations shall recognize any liability due at the time of provision of the worker to any service thereto to meet the benefits of the employees to be paid to them in the future and to any expense when the institution consumes the economic benefits arising from the service provided by the employee for benefits or privileges to the workers (ASCA, 2015).

There are several studies discussed the importance of job satisfaction in Jordanian banks (Al-Hawary, Al-Qudah, Abutayeh, Abutayeh, \& Al-Zyadat, 2013). However, any study did not discuss the impact of spending on employees and its impact on enhancing the financial performance of the bank. This study examined the relationship between spending on employees in Jordanian commercial banks based on whatever other expenses were spent on the employees (medical, life insurance, travel, training and social security), at each market share price (where average of daily closing prices was adopted), and on the valume of credit facilities as well as the volume of deposits, which considered the main source of financing for the banking sector, on which they establsih tehir business (Barbosa, Bilan, \& Celerier, 2017; Lode, \& Napier, 2014; Dewi, 2015; Liapis, \& Thalassinos, 2013). The results of this study, which attempts to measure the impact of employee benefits on both the average of market share price which is considered as a strength of the bank, as well as the volume of credit facilities granted to customers, which are considered the main source of income and the resultant interest and 
profits through granting credit facilities. But before granting credit, it should be focused on the source of funding, i.e deposits which are deposited in banks in which the bank utilize them through granting credit. Therefore, it is expected to be a subject of interest by the departments of banks and the concerned parties thereof.

\section{Previous Literature}

Through the concept of direct compensation about the kind of financial price in the form of (salaries, wages, financial allowances, financial rewards, financial incentives) (Brouwer \& Hoogendoorn, 2017), which is provided within a short period of time (a month, a week) by the employer to any worker by the difference of his jobs for his provision to his effort, time and skill to serve and achieve the objectives of the organization (Amen, 2007). While the indirect compensation refers to all the cash and non- cash benefits and rewards provided to the employees by the institution where they work therein (Hoogendoorn, 2006), because they are members working therein, so providing to them is not connected to the performance and activity (Barbosa, Bilan, \& Celerier, 2017). These incentives are called Employee benefits, which are a variety of services with a financial value services provided by organizations to all their employees as freely, or covering part of their cost (Frye, 2004), with no exceptions (for permanent employees only) and regardless of the level of their performance and efficiency at work, they are offered to them as their members working therein. The administration bears great burdens and costs while managing the compensation (Hoogendoorn, 2006), and therefore it must make strategic decisions to achieve the desired benefit from the management of such compensation (Frye, 2004). Most business organizations see compensation as a spending investment that achieves a high level of employee performance and increases customer satisfaction and makes it a popular place to work (Amen, 2007). It helps them attract human resources from the labor market and at the same time maintaining their human competencies and not leaking them to other organizations (Fujiwara \& Ogawa, 2017). On the other hand, other business organizations consider compensation as a cost that affects their profitability and must be limited. This strategy has negative impacts on the organization; the most important of these are the escape of other human competencies to other organizations and the survival of human resources with normal performance and efficiency (Hoogendoorn, 2006; Brouwer \& Hoogendoorn, 2017). This negatively affects their production and impassiveness and the loss of their customers. Over time, it is true that this strategy provides money to the organization (Amen, 2007), but this savingwill be eroded by the low level of customer satisfaction and sales figures, coupled with the possibility of high turnover and the difficulty of attracting the need of manpower from the labor market. There are business organizations that have a view of compatibility between the two previous points of view, whereby the institution can achieve attractions and prevent the leakage of human resources to other organizations and achieve external equality in compensation (Amen, 2007), but it does not make it distinct from other organizations and in general very common use of this strategy because it represents a moderate trend in compensation (Frye, 2004; Fujiwara, \& Ogawa, 2017). The current service cost is defined as the increase in the present value of a specific benefit obligation that arises thereof, because the benefits are closer to a one-time payment. To measure the obligation of the identified benefits, business organizations use the estimated additional unit method to determine the present value of their defined benefit obligations, The increase in the present value of the liability for the specific benefits arising from the employee's service in the current period (or the cost of the previous service), it is the increase in the present value of the obligation to service benefits in prior periods resulting from the current period. The benefits of the previous service may be either (positive) where benefits are introduced or improved or (negative) where existing benefits are reduced (Fujiwara \& Ogawa, 2017). This method covers each service period which creates an additional unit increase in the benefit entitlement and each unit is measured separately to form the ultimate obligation. In order to calculate the present value of the obligation of the enterprise towards the workers, end of service benefits (the final salary) must be determined, due benefits, financial assumptions, demographic assumptions and revenues of the assets of the plan (ASCA, 2015, IAS, 19). Profitability is the primary objective of business organizations, especially banks. However, with the development of financial management science, such has become a past. As it is became calling to gloryingthe wealth of owners and thus enhancing their financial position as well as enhancing their competitiveness (Fasshauer, Glaum, \& Street, 2008), but the mechanism of achieving this objective is to adopt a modern and unconventional approach of work (Gold, 2005). Where banks seek to motivate employees through different methods(eg, rewarding salaries, training, bonuses, insurance etc.), but these methodscost banks a range of expenses. In addition, the employees benefits have positive impacts on the stability of the political system in each country, and their impact on the stability of the political life and political system of the state is shown in defusing the confrontation between workers and employers in the event of the infection of any social risk to the worker, as the employers contribute with a share specified by the law in subscription in the social insurance in anticipation to whatever shall inflict the emploee of social risks on one hand (Ghanem, 2002). On the other hand, it releaves the state from any possible confrontation with employers if the state imposed remittance taxes for the workers who might be affected by 
some social risks.

Therefore, the application of employee benefit accounting is necessary to achieve social security and emphasis volume the importance of benefiting from productive household activities and social security, and the need to develop the relationship between social security activities in social unity and social security for citizens (Najeeb, 2009). As well The contributions of accounting thought and practical practice in the area of employee benefit accounting forms an important factor in preventing misuse of the individual's financial resources, either by reducing his income or by increasing his expenses. This applies to all risks, whatever their personal, professional or social causes (Ghanem, 2002; Westlund, Ermolieva, \& MacKellar, 2000; Najeeb, 2009) emphasis volumethe development of social insurance laws and accounting standards for the better in order to avoid falling into (Nabulsi, 2010) noted that the system of employee benefits in Jordan is bankrupt and it has characteristics that made it a different and backward system, The approach taken by employee benefit accounting is a partial funding approach. As it is expected that if there are not substantial changes in employee benefit accounting policies, companies will experience a wave of erosion in their future financial situation due to the expected increase in the percentage of seniority in Jordan (IMF) (2004) (Note 2), also noted that the status of the Social Security Institution is vulnerable exposed to imbalance in the coming years. And I criticized the investment policy of the institution, where (Nabulsi, 2010) sees that the investment policy of the institution of social security is to avoid risks Extremely exaggerated at the expense of investment return. On the other hand, (Nabulsi, 2010) asserted that the rate of nominal return on investments are low, they are lowering increasingly and became negative in some years if the results of their investments were considered based on the real return rate index, i.e. after reducing the impact of inflation. The study also indicated that the most severe investment policies of the institution results came as a result of diminishing the institution's contribution to the Jordanian financial market development. Although the sectoral indices initially indicate a slight increase in the share of contributions to the Jordanian companies at the end of 2015 , so that the contribution total investment rate rose of $14.7 \%$ to $16.9 \%$. However; examining the actual development of the contributions of the institution in Jordanian companies indicates that the role of the financing institution in the financial market was mostly limited to causious and por-studied underwriting mostly in new companies, with almost complete abstention from investment operations through direct and active intervention in the financial market and trading in the capital market, i.e. the investment insitution has, due to the weakness of invetsment managment and the lack of investment capability, refrained from trading operations and seized investment opportunities inititives in the stocks and debentures market and thus negatively affected the domestic investment rates. (Ghanem, 2002) pointed out that the assessment of the employees benefits according to the national accounting plan did not take into account economic changes indicators such as labor turnover rates, development rates, death rates, and non-use of fair value, which will consequent on inaccurateassessment thereof which will lead to negative consequences represented in giving a true look in the financial statements. And the infliction of institution to social problems, ie workers' dissatisfaction. As well as management problems, that are unpredictability of future costs. It also leads to the non-allocation of funds in the form of subsidies recognized in the general budget, which leads the institution to financial problems, ie liquidity risk. (Hanlon \& Terry, 2002). recommended that accounting practices relatedto social welfare reforms should be applied to the lives of institutional social assistance beneficiaries by developing unified international standards to ensure consistency of financial reports and accounting lists. (Hanlon \& Terry, 2002) also pointed to the need for a number of corrective measures to maintain a sound and sustainable financial position in respect of employee benefitsaccounting of companies. As well as strengthening and promoting investment policy in the area of employee benefitsaccounting. And reviewing the performance of the investment portfolio of the company or the evaluation of investment managers. (Westlund, Ermolieva, \& MacKellar, 2000) stressed the need for accounting systems for employee benefits, which is to reduce the negative impacts of the application of inefficient systems. These systems are inherent in the long-term analysis of employee benefit schemes and stemming from, other resourcesincluding uncertainty in demographic projections, savings rates of the individual, household sector and labor force participation rates. With direct implications forstaff benefit accounting systems. Where these systems have become the subject of many questions. Long-term expectations of the income and expenditure of employee benefit accounting systems and the accumulation of money balances in corporate funds play a role in determining and shaping the policy governing these funds (Mc Morrow \& Roeger, 2002).

\section{Hypotheses}

Hypotheses of the study based on previous literature, the hypotheses can be formulated as follows:

\section{HOa: there is not an impact of direct employees compensation on market share price.}

H0a-1: There is not an impact of direct employees compensation on market share price. 
H0a-2: There is not an impact of indirect compensation on market share price.

HOb: There is not an impact of employee compensation on the volume of credit facilities granted to customers.

H0b-1: There is not an impact of direct compensation on the volume of credit facilities granted to customers.

H0b-2: There is not an impact of indirect compensation on the volume of credit facilities granted to customers.

HOc: There is not an impact of employees compensation on customer deposits the volume.

H0c-1: There is not an impact of direct compensation on customer deposit volume.

H0c-2: There is not an impact of indirect compensation on the of customer deposits volume.

\section{Methodology of the Study}

This study is one of the qualitative studies in data analysis (Creswell, 2009; Miles, Huberman, \& Saldana, 2013). As data and information were collected and analyzed to test hypotheses (Saunders, 2011). And we grounded on the data published on the Amman Stock Exchange (2016) (Note 3), the annual reports issued by the studies commercial banks, and the reports issued by the Association of Jordanian Banks in order to reach the volume of credit facilities granted by the commercial banks, in addition to the volume of deposits obtained during the study period. Previous literature was also used to build the theoretical framework. Accordingly, the financial statements of the Jordanian commercial banks were analyzed. The employees' benefits were considered as all forms of compensation given by the bank for the service provided by the employees of those banks. In addition, employee benefits include payment transactions on the basis of shares by which employees receive equity instruments (such as shares or share options), cash or other assets of the Bank in amounts based on the share price of the Bank's share-based payment accounting or other equity instruments owned by the Bank. The Bank should recognize the cost of employee benefits due to the service rendered to the Bank during the reporting period as a liability or an expense (Note 4).

\subsection{Society and Sample of Study}

The study community consists of all the commercial banks listed on the Amman Stock Exchange (2007-2015) (Note 5), and the number of (13) banks. Taking into the account the conditions that must be met by these banks as required by the objective of the study in terms of availability of financial data for these companies during the study period. In addition, data on the study variables will be fully available. Accordingly, the study included all Jordanian commercial banks of their meeting to the requirements of the study (Jordan Banks Guide, 2016) (Note $6)$.

\subsection{Methods of Data Analysis}

The Statistic software (E-Views) was used to test the hypotheses of the study (LaGuardia, 2005). This software is characterized by a variety of types of tests. The data are Panel Data. It relied on descriptive statistics to describe variables studying. In addition to the Unit Root Test to determine the stability of the data of the study variables. And finally the Multiple Regression - Panel EGLS analysis to test hypotheses (Hsiao, 2014; Miles, Huberman, \& Saldana, 2013, Ou \& Penman, 1989)

\subsection{Description of Study Variables}

The table below summarizes the results of descriptive statistics of the study variables.

Table 1. Summary of results of descriptive statistics

\begin{tabular}{lccccc}
\hline \multicolumn{1}{c}{ Variable } & Code & Mean & Standard deviation & Max & Min \\
\hline Directcompensations & D_COMP & $26,556,267$ & $39,970,289$ & $182,026,000$ & $2,260,605$ \\
Indirect compensation & IND_COMP & $5,446,444$ & $6,827,586$ & $32,547,000$ & 430,579 \\
Average of market share price & MS & 3.34 & 3.62 & 23.92 & 0.88 \\
Credit facilities & DCF & $865,732,701$ & $664,581,584$ & $2,912,000,000$ & $99,000,000$ \\
Customers deposits & CD & $1,530,434,385$ & $1,652,841,058$ & $7,604,000,000$ & $109,590,000$ \\
\hline
\end{tabular}

Note. Prepared by the researchers upon the results of a statistical analysis.

\section{- Direct compensations:}

The mean of direct compensation volume was (JD 26,556,267) and a standard deviation of (JD 39,970,289). The direct compensation ranged from minimum (2,260,605 JD) to maximum (JD 182,026,000). This indicates that there is a difference in the amount of direct compensation attributed to the number of employees in addition to the variation in the system of salaries and bonuses between commercial banks. 


\section{- Indirect compensation:}

The mean of indirect compensation was (JD 5,446,444) and a standard deviation of (JD 6,827,586). The indirect compensation ranged between minimum (JD 430,579) and maximum (JD 32,547,000). This indicates that there is a variation in the volume of indirect compensation, which is due to the Bank's policy of spending on training and medical expenses.

\section{- Average Market Price:}

The average market share price was (JD 3.34) and a standard deviation of (JD 3.62). The average market price ranged from minimum (JD 0.88) to maximum (JD 23.92). This indicates that there is a variation in the average market share price, which is attributed to the strength of the share in addition to the status of commercial banks of good reputation granted its shares a good market strength).

\section{- Credit facilities:}

The meanof volume credit facilities was (JD 865,732,701) and a standard deviation of (JD 664,581,584). The credit facilities ranged between minimum (JD 99,000,000) to maximum of $(2,912,000,000)$. This indicates that there is a variation in the volume of granted credit facilities, as this is attributed to the nature and strength of commercial banks in addition to the volume of money invested funds therein.

\section{- Customer Deposits:}

The meanof volume customer deposits was (JD 1,530,434,385) and standard deviation of (JD 1,652,841,058), the credit facilities ranged between minimum (JD 109,590,000) and a maximum of (JD 7,604,000,000). This indicates that there is a variation in the volume of deposits attributed to the capability of commercial banks to bring funds from customers as which such banks are characterized ofstrong financial policies to invest these funds in the manner that shall generate profits to the customers and the bank. In addition to being subject to multiple regulatory bodies that guarantee financial and economic stability.

\section{Unit Root Test}

The data instability issue is an important issue and a point to be considered. As the data are Panel Data, the (Levin, Lin \& Chu) test was used to determine the stability of the data during the period (2007-2015) Table 2 Shows the results:

Table 2. Results of Unit Root Test for data stability by using (Levin, lin \& Chu) Test

\begin{tabular}{lccc}
\hline Variable & Code & t-statistic & Probability \\
\hline Directcompensations & D_COMP & -8.02383 & 0.000 \\
Indirect compensation & IND_COMP & -16.1833 & 0.000 \\
Average of market share price & MS & -18.449 & 0.000 \\
Credit facilities & DCF & -5.19515 & 0.000 \\
Customers deposits & CD & -1.76626 & 0.0387 \\
\hline
\end{tabular}

Note. Prepared by the researchers upon the results of a statistical analysis.

Table 2 shows that all the statistical significance values (Probablity) of the Levin, Lin \& Chu tests are statistically significant (less than 5\%). Therefore, all the variables of the study are stable at their level.

\section{Statistical Processing of the Study Financial Data}

In order to test the hypotheses of the study, the linear regression analysis of the financial statements of commercial banks was used within the period of time (2007-2015) in an annual basis.

\section{Testing Hypotheses}

H0a: was tested by using the standard model to test multiple linear regression of data. The relationship between the average market share price as a dependent variable, direct compensation and indirect compensation was represented as independent variables in the following general linear model:

$$
M S_{c t}=a+\beta 1 D_{-} C O M P_{c t}+\beta 2 I N D_{-} C O M P_{c t}+e
$$

This model was estimated by using (Panel EGLS) in order to test H0a. We obtained the results shown in Table 3 By using the software of (E-views). 
Table 3. Results of regression equation of impact of compensations on the average market share price

\begin{tabular}{|c|c|c|c|c|}
\hline $\begin{array}{l}\text { Dependent Variable: Average of market sh } \\
\text { Method: Panel EGLS (Cross-section weigl } \\
\text { Sample: 2007-2015 } \\
\text { Periods included: } 9 \\
\text { Cross-sections included: } 13 \\
\text { Total panel (balanced) observations: } 117 \\
\text { White cross-section standard errors \& cove }\end{array}$ & & & & \\
\hline Variable & Coefficient & Std. Error & $\mathrm{t}$-Statistic & Prob. \\
\hline Direct compensations & $-4.12 \mathrm{E}-08$ & $1.56 \mathrm{E}-08$ & -2.632169 & 0.0097 \\
\hline Indirect compensation & $6.40 \mathrm{E}-07$ & $5.73 \mathrm{E}-08$ & 11.16998 & 0.0000 \\
\hline $\mathrm{C}$ & 0.757815 & 0.180320 & 4.202618 & 0.0001 \\
\hline R-squared & 0.702302 & & & \\
\hline Adjusted R-squared & 0.697080 & & & \\
\hline S.E. of regression & 1.963775 & & & \\
\hline F-statistic & 134.4694 & & & \\
\hline
\end{tabular}

Note. Prepared by the researchers upon the results of a statistical analysis.

Table 3 shows the results of the regression equation byusing the average market share price as a dependent variable, where it was found that there is a statistically significant impact of the volume of the total compensation which was measured through (direct compensation and indirect compensation). The value of calculated coefficient (F) calculated at (134.4694) and with level of statistical significance of (Prob. $=0.000$ ), where we induce that it was less than $(0.05 \%)$, accordingly we reject H0a-1 and accept H1a-1. The regression equation in the table shows a high explanatory value, with the value of the $\left(\mathrm{R}^{2}\right)$ and the (adjusted $\mathrm{R}^{2}$ ) parameter (70.2\% and $69.7 \%$ respectively). The independent variables explain $70.2 \%$ of the variable of the average market price. On the other hand. the results of the study showed that the coefficients values of the direct compensation variable has a negative and significant impact on the average price of the market share. The calculated t-statistic value was $(-2.632169)$ and at a significant level of (Prob $=0.0097)$, which is below the level of statistical significance $(0.05 \%)$, this means that the direct compensation of salaries and bonuses received by employees in commercial banks negatively affect the average share price. In addition, the results of the study showed that there was a positive relationship between the indirect compensation variable and the average market share price, where the value of t-Statistic is calculated at (11.16998) with the level of significance of (Prob. $=0.000$ ). This means that there is a positive and significant impact of indirect compensation on average market price. Accordingly, H0a-1, H0a-2 is rejected and replaced by H1a-1, H1a-2.

H0b: was tested using the standard model to test multiple linear regression of data. The relationship between the volume of credit facilities as a dependent variable, direct compensation and indirect compensation was represented as independent variables in the following general linear model:

$$
D C F_{c t}=a+\beta 1 D_{-} C O M P_{c t}+\beta 2 I N D \_C O M P_{c t}+e
$$

To test H0b, this model was estimated by using Panel EGLS. We obtained the results shown in Table No. (4) By using E-views software.

Table 4. Results of Regression equation of impact of compensations on the volume of credit facilities

\begin{tabular}{|c|c|c|c|c|}
\hline $\begin{array}{l}\text { Dependent Variable: Credit facilities (D } \\
\text { Method: Panel EGLS (Cross-section we } \\
\text { Sample: 2007-2015 } \\
\text { Periods included: } 9 \\
\text { Cross-sections included: } 13 \\
\text { Total panel (balanced) observations: } 117 \\
\text { White cross-section standard errors \& c }\end{array}$ & & & & \\
\hline Variable & Coefficient & Std. Error & t-Statistic & Prob. \\
\hline Direct compensations & 8.278668 & 3.123373 & 2.650554 & 0.0092 \\
\hline Indirect compensation & 42.49955 & 17.55062 & 2.421541 & 0.0170 \\
\hline $\mathrm{C}$ & $4.12 \mathrm{E}+08$ & 13373855 & 30.80120 & 0.0000 \\
\hline R-squared & 0.740908 & & & \\
\hline Adjusted R-squared & 0.736362 & & & \\
\hline S.E. of regression & $2.99 \mathrm{E}+08$ & & & \\
\hline F-statistic & 162.9987 & & & \\
\hline Prob(F-statistic) & 0.000000 & & & \\
\hline
\end{tabular}

Note. Prepared by the researchers upon the results of a statistical analysis. 
Table 4 shows the results of the regression equation by using the volume of credit facilities as a dependent variable, where it was found that there is a statistically significant impact of the volume of the compensation as a whole which was measured through (direct and indirect compensations) in commercial banks on the volume of credit facilities, where the value of calculated coefficient (F) was (162.9987) and the level of statistical significance (Prob. $=0.000$ ), where we indicate that it was less than $(0.05 \%)$, and therefore we reject H0b and accept $\mathrm{H} 1 \mathrm{~b}$, and the regression equation in the table shows high explanatory value where the value of the coefficient of determination $\left(\mathrm{R}^{2}\right)$ and the coefficient of determination rate (Adjusted $\mathrm{R}^{2}$ ), $(74.09 \%)$ and $(73.6 \%)$ respectively, i.e. independent variables explain the percentage of $(74.09 \%)$ of the changes in the dependent variable of the volume of the credit facilities. On the other hand, the results of the study showed that the regression coefficient of the direct compensation variable has a positive and significant impact on the volume of the credit facilities. The calculated t-statistic value was (2.650554) at a significant levelof (0.0092), which is less than the statistical significance level $(0.05 \%)$. This means that the direct compensation represented by the salaries and bonuses received by the employees positively affects the volume of credit granted. In addition, the results of the study showed that there is a positive relationship between the indirect compensation variable and the volume of the credit facilities, where the value of t-Statistic was calculated at (2.421541) with the level of significance (Prob. $=0.0170$ ). This means that there is a positive and significant impact of the indirect compensation on the volume of credit facilities. Accordingly, it rejects both of (HOb-1, HOb-2) and instead we accept in their place (H1b-1, H1b-2).

HOb: was tested using the standard model to test multiple linear regression of data. The relationship between the volume of deposits as a dependent variable, direct compensation and indirect compensation was represented as independent variables in the following general linear model:

$$
C D_{c t}=a+\beta 1 D_{-} C O M P_{c t}+\beta 2 I N D \_C O M P_{c t}+e
$$

To test H0c, this model was estimated by using Panel EGLS. We obtained the results shown in Table No. (5) By using E-views software.

Table 5. Results of regression equation of impact of compensations on the volume of deposits

\begin{tabular}{|c|c|c|c|c|}
\hline \multicolumn{5}{|l|}{ Dependent Variable: Customers deposits (CD) } \\
\hline \multicolumn{5}{|l|}{ Method: Panel EGLS (Cross-section weights) } \\
\hline \multicolumn{5}{|l|}{ Sample: $2007-2015$} \\
\hline \multicolumn{5}{|l|}{ Periods included: 9} \\
\hline \multicolumn{5}{|l|}{ Cross-sections included: 13} \\
\hline \multicolumn{5}{|l|}{ Total panel (balanced) observations: 117} \\
\hline \multicolumn{5}{|c|}{ White cross-section standard errors \& covariance (d.f. corrected) } \\
\hline Variable & Coefficient & Std. Error & $\mathrm{t}$-Statistic & Prob. \\
\hline Direct compensations & 34.29010 & 2.320827 & 14.77495 & 0.0000 \\
\hline Indirect compensation & 28.26312 & 16.76996 & 1.685342 & 0.0947 \\
\hline $\mathrm{C}$ & $3.65 \mathrm{E}+08$ & 40020510 & 9.122627 & 0.0000 \\
\hline R-squared & 0.788060 & & & \\
\hline Adjusted R-squared & 0.784341 & & & \\
\hline S.E. of regression & $5.40 \mathrm{E}+08$ & & & \\
\hline F-statistic & 211.9437 & & & \\
\hline Prob(F-statistic) & 0.000000 & & & \\
\hline
\end{tabular}

Note. Prepared by the researchers upon the results of a statistical analysis.

Table 5 shows the results of the regression equation by using the volume of deposits (CD) as a dependent variable, where it was found that there is a statistically significant impact of the volume of the compensation as a whole which was measured through (direct and indirect compensations) in commercial banks on the volume of deposits, where the value of calculated coefficient (F) was (211.9437) and the level of statistical significance (Prob. $=0.000)$, where we indicate that it was less than $(0.05 \%)$, and therefore we reject H0c and accept H1c, and the regression equation in the table shows high explanatory value where the value of the coefficient of determination $\left(\mathrm{R}^{2}\right)$ and the coefficient of determination rate (Adjusted $\mathrm{R}^{2}$ ), (78.8\%) and (78.46\%) respectively, i.e. independent variables explain the percentage of $(78.8 \%)$ of the changes in the dependent variable of the volume of the deposits. On the other hand, the results of the study showed that the regression coefficient of the direct compensation variable has a positive and significant impact on the volume of deposits. The calculated t-statistic value was (14.77495) at a significant level of $(\mathrm{Prob}=0.0000)$, which is less than the statistical 
significance level $(0.05 \%)$. This means that the direct compensation represented by the salaries and bonuses received by the employeespositively affects the volume of deposits. In addition, the results of the study showed that there is a positive relationship between the indirect compensation variable and the volume of the deposits, where the value of $t$-Statistic was calculated at $(1.685342)$ with the level of significance (Prob. $=0.0947)$. This means that there is not the significant impact of the indirect compensation on the volume of deposits. Accordingly, we reject ((H0c-1) and we accept in their place (H1b-1, H0b-2).

\section{Conclusion}

The purpose of this study was to investigate the impact of employee benefit accounting on market price, volume of credit facilities and deposits and whether there was a difference in this impact according to direct and indirect compensation. Which are available during the period of study (2007-2015) represented in (13) commercial banks. The study was based on qualitative data in data analysis, (E-Views) economic statistics software was used to test hypotheses. The results of the study showed that there is a statistically significant impact on both typesof employees compensations as a whole (direct and indirect) on the market share price, the volume of credit facilities and the volume of deposits. While the results of the study confirmed that the indirect compensation has not got an impact on the volume of customer deposits when it is measured separately. Finally, the study recommended the need to apply good employee benefit systems in addition to the necessity to assess the impact of those systems periodically to reduce the negative impacts resulted from the useless systems for its negative impact on the financial performance of banks represented in profitability.

\section{References}

Al-Hawary, S. I., Al-Qudah, A. K., Abutayeh, P. M., Abutayeh, S. M., \& Al-Zyadat, D. Y. (2013). The impact of internal marketing on employee's job satisfaction of commercial banks in Jordan. Interdisciplinary Journal of Contemporary Research in Business, 4(9), 811-826.

Amen, M. (2007). Simulation-based comparison of existent IAS 19 accounting options. European Accounting Review, 16(2), 243-276. http://dx.doi.org/10.1080/09638180701390925

Barbosa, L., Bilan, A., \& Celerier, C. (2017). Credit Supply Shocks and Human Capital: Evidence from a Change in Accounting Norms. Retrieved https://ssrn.com/abstract=2981127 or http://dx.doi.org/10.2139/ssrn.2981127

Brouwer, A., \& Hoogendoorn, M. (2017). The role and current status of IFRS in the completion of national accounting rules-Evidence from the Netherlands. Accounting in Europe, 1-2. 134-149. http://dx.doi.org/10.1080/17449480.2017.1300674

Creswell, J. W. (2009). Editorial: Mapping the field of mixed methods research. Journal of Mixed Methods Research, 3(2), 95. https://doi.org/10.1177/1558689808330883

Dewi, N. H. U. (2015). Adaptability Fair Value Accounting at The Public Company in Indonesia. PEOPLE: International Journal of Social Sciences, 1(1), 754-770.

Fasshauer, J. D., Glaum, M., \& Street, D. L. (2008). Adoption of IAS 19R by Europe's premier listed companies: Corridor approach versus full recognition: Summary of an ACCA research monograph. Journal of International Accounting, Auditing and Taxation, 17(2), 113-122. https://doi.org/10.1016/j.intaccaudtax.2008.07.005

Frye, M. B. (2004). Equity - based compensation for employees: Firm performance and determinants. Journal of Financial Research, 27(1), 31-54.https://doi.org/10.1111/j.1475-6803.2004.00076.x

Fujiwara, H., \& Ogawa, Y. (2017). Estimating Compensation of Employees Based on Taxation Data. The Japanese Economic Review. https://doi.org/10.1111/jere.12158

Ghanem, M. El S. (2002). The Origins and Development of Social Insurance in Egypt. Presented to the Conference of Social Insurance between Reality and Hope, held from 13-15 October 2002, Saleh Abdullah Kamel Center for the Islamic economy.

Glaum, M., Keller, T., \& Street, D. L. (2017). Discretionary accounting choices: The case of IAS 19 pension accounting. Accounting and Business Research, 1-32. http://dx.doi.org/10.1080/00014788.2017.1354760

Gold, J. (2005). Accounting/actuarial bias enables equity investment by defined benefit pension plans. North American Actuarial Journal, 9(3), 1-21. http://dx.doi.org/10.1080/10920277.2005.10596209

Hanlon, M., \& Shevlin, T. (2002). Accounting for tax benefits of employee stock options and implications for research. Accounting Horizons, 16(1), 1-16. https://doi.org/10.2308/acch.2002.16.1.1 
Hoogendoorn, M. (2006). International accounting regulation and IFRS implementation in Europe and beyondexperiences with first-time adoption in Europe. Accounting in Europe, 3(1), 23-26. http://dx.doi.org/10.1080/09638180600920087

Hsiao, C. (2014). Analysis of panel data (No. 54). Cambridge university press. https://doi.org/10.1017/CBO9781139839327

LaGuardia, C. (2005). Infotech-E-Views And Reviews-Scopus VS. Web of Science. Library Journal, 130(1), 40-43.

Liapis, K., \& Thalassinos, E. (2013). A Comparative Analysis for the Accounting Reporting of "Employee Benefits" between IFRS and other Accounting Standards: A Case Study for the Biggest Listed Entities in Greece. International Journal of Economics \& Business Administration, 1(1), 91-116.

Locke, R. M., Rissing, B. A., \& Pal, T. (2013). Complements or substitutes? Private codes, state regulation and the enforcement of labour standards in global supply chains. British Journal of Industrial Relations, 51(3), 519-552.http://dx.doi.org/10.1111/bjir.12003

Lode, N. A., \& Napier, C. J. (2014). Recognition of Actuarial Gains and Losses under IAS 19 among UK Listed Companies. Jurnal Pengurusan (UKM Journal of Management), 40, 15-24. https://doi.org/10.17576/pengurusan-2014-40-02

Mc Morrow, K., \& Roeger, W. (2002). EU pension reform-An overview of the debate and an empirical assessment of the main policy reform options (No. 162). Directorate General Economic and Financial Affairs (DG ECFIN), European Commission.

Miles, M. B., Huberman, A. M., \& Saldana, J. (2013). Qualitative data analysis. Sage.

Nabulsi, M. S. (2010). Study of Reforming the Pension and Social Security Systems in Jordan and its Relationship to Investment Development. Jordan Development Center, Amman.

Najeeb, S. (2009). The Compatibility between social security measures and the mechanisms to achieve this at the regional and national levels. Working paper submitted to the Arab Social Security Conference entitled: Towards Effective Social and Insurance Policies in the Arab World, held in Sharm El-Sheikh, From 19 to 21 December 2009.

Ou, J. A., \& Penman, S. H. (1989). Financial statement analysis and the prediction of stock returns. Journal of Accounting and Economics, 11(4), 295-329. https://doi.org/10.1016/0165-4101(89)90017-7

Saunders, M. N. (2011). Research methods for business students, 5/e. Pearson Education India.

Westlund, A., Tatiana, E., \& Landis, M. (2000). Analysis and forecasting of social security: A study of robustness. Financial Modelling, 401-427. https://doi.org/10.1007/978-3-642-57652-2_27

\section{Notes}

Note 1. The International Arab Society of Certified Accountants (IASCA) was established on January 12, 1984 as a non-profit professional accounting association in London, UK. It was formally registered in Amman on February 24, 1994 under the name "The Arab Society of Certified Accountants". See http://www.ascasociety.org/page.aspx?page_key=asca\&lang=en

Note 2. IMF (2004). Jordan: Selected Issues and Statistical Appendix. Country Report No. (4/121). See https://dokumen.tips/education/economic-developments-and-outlook-for-the-jordan-1994-2004.html

Note 3. See http://www.abj.org.jo/ar-jo/home.aspx

Note 4. http://www.ifrs.org/Use-around-the-world/Education/Pages/IFRS-Teachers.aspx

Note 5. See http://www.ase.com.jo/ar/equities

Note 6. http://guide2jordan.com/banks

\section{Copyrights}

Copyright for this article is retained by the author(s), with first publication rights granted to the journal.

This is an open-access article distributed under the terms and conditions of the Creative Commons Attribution license (http://creativecommons.org/licenses/by/4.0/). 